\title{
Hawai'i Hawai'i
}





\section{Hawai'i Hawai'i}

Rick Golt photographer

Clemente Lagundimao, Jr. designer

A Kolowalu Book The University Press of Hawaii Honolulu 
Copyright $\odot 1981$ by The University Press of Hawaii All rights reserved

Library of Congress Catalog Card Number 81-50935

ISBN 0-8248-0772-3

Manufactured in the United States of America 